\title{
First record of Hysterothylacium sp. Moravec, Kohn et Fernandes, 1993 larvae (Nematoda: Anisakidae) infecting the ornamental fish Hyphessobrycon eques Steindachner, 1882 (Characiformes, Characidae)
}

\author{
Acosta, $A A{ }^{a *}$ and Silva, RJ. ${ }^{a}$ \\ aPrograma de Pós Graduação em Zoologia, Laboratório de Parasitologia de Animais Silvestres, \\ Departamento de Parasitologia, Instituto de Biociências, Universidade Estadual Paulista - UNESP, \\ Distrito de Rubião Júnior, s/n, CEP 18618-970, Botucatu, SP, Brazil \\ *e-mail: alineacosta1@gmail.com
}

Received: November 7, 2013 - Accepted: March 17, 2014 - Distributed: August 31, 2015

(With 2 figures)

\begin{abstract}
This study reports for the first time infection with Hysterothylacium sp. larvae in the ornamental fish Hyphessobrycon eques from the Paranapanema River, Jurumirim Reservoir, São Paulo State, Brazil. A sample of 33 specimens of H. eques was collected in October, 2011. Four specimens of H. eques were parasitized by Hysterothylacium sp. larvae in the intestine and coelomic cavity, with prevalence of $12.1 \%$, mean intensity of infection of 1 , and mean abundance of $0.121 \pm 0.05$. A total of 40 unidentified free-living nematodes were found in the stomach content of 17 fish. This fish species is introduced in the Paranapanema River. Invasive species may affect the native fauna given the introduction of pathogens and parasites. This study also complements data on the diet of $H$. eques due to the records of free-living nematode as part of the stomach content. Infections with Hysterothylacium sp. larvae may affect the biology of this fish and bring about profit losses to aquarists.
\end{abstract}

Keywords: characidae, helminth, nematode, parasites, disease.

\section{Primeiro registro de larvas de Hysterothylacium sp. Moravec, Kohn et Fernandes, 1993 (Nematoda: Anisakidae) infectando o peixe ornamental Hyphessobrycon eques Steindachner, 1882 (Characiformes, Characidae)}

\begin{abstract}
Resumo
Este estudo reporta pela primeira vez infecção com larva de Hysterothylacium sp. no peixe ornamental Hyphessobrycon eques do rio Paranapanema, reservatório de Jurumirim, estado de São Paulo, Brasil. Uma amostra de 33 spécimens de H. eques foi coletada em Outubro de 2011. Quatro espécimes de H. eques estavam parasitados por larva de Hysterothylacium sp. no intestino de cavidade celomática, com prevalência baixa de $12,1 \%$, intensidade média de infecção de 1 e abundância média de $0,121 \pm 0,05$. Um total de 40 nematóides livres não identificados foi encontrado no conteúdo estomacal de 17 peixes. Esta espécie de peixe é introduzida no rio Paranapanema. Espécies invasoras podem afetar a fauna nativa dada a introdução de patógenos e parasitas. Este estudo também complementa os dados de alimentação de $H$. eques devido os registros de nematoides de vida livre como parte do conteúdo estomacal. Infecções com larva de Hysterothylacium sp. afetam a biologia deste peixe e pode ocasionar prejuízos para aquaristas.
\end{abstract}

Palavras-chave: caracídeo, helminto, nematoda, parasitas, doença.

\section{Introduction}

Hyphessobrycon Durbin, 1908 is a genus of the family Characidae that ranks the second place in number of valid species (Eschmeyer and Fong, 2011). The species of this genus are widely distributed in the Neotropical region, occurring from the South of Mexico to Argentina (Lima and Moreira, 2003), with more than one third of the species found in the Amazon River basin (Lima et al., 2003). The exuberant colorful patterns presented in several Hyphessobrycon species make them valuable in the ornamental freshwater fish trade market (Carvalho, 2011). In Brazil, this trade is restricted to the Amazon region, however Pelicice and Agostinho (2005) studied the perspectives on ornamental fisheries in the Upper Parana River floodplain, Brazil and found out a great potential in this area for the activity.

Hyphessobrycon eques Steindachner, 1882 is world widely known as serpa tetra (Carvalho and Del-Claro, 2004) 
or jewel tetra (Fujimoto et al., 2013) and as "mato grosso" in Brazil (Duke Energy, 2008). This fish is part of the "rosy tetra clade" suggested by Weitzman and Palmer (1997). The species of this clade are mainly characterized by the reddish color of the body and caudal fin in adult males, and dorsal fin bigger than the others with a spot on its end (Weitzman and Palmer, 1997). This species is distributed in the Amazon and Paraguay River basins (Weitzman and Palmer, 1998). However, it is found along the Paranapanema River in the shoal areas of reservoirs and tributaries, thus considered an allochthonous species in this region (Brandão et al., 2009). Hyphessobrycon eques is an invasive species in the Upper Parana River and its occurrence may be related to its use by aquarists (Graça and Pavanelli, 2007). The introduction of species may affect the native fauna due to competition, predation, habitat and genetic alteration, and introduction of pathogens and parasites (Agostinho et al., 2007).

Studies with $H$. eques have been conducted under different approaches: ornamental use (Pan et al., 2011; Morais, 2013), feeding behavior (Carvalho and Del-Claro, 2004), association with macrophytes (Pelicice et al., 2005), indicator of water quality (Carraschi et al., 2011), and diet (Casatti et al., 2003; Crippa et al., 2009; Santana-Porto and Andrian, 2009); however the study of Fujimoto et al. (2013) is the only assessment on its parasite fauna. These last authors recorded seasonal occurrence of Quadrigyrus nickoli Schmidt and Hugghins, 1973 cystacanths in H. eques from the Chumucuí River, Pará State, Brazil.

Parasites indicate several biological aspects of their hosts, and they may also be used as bioindicators of environmental quality (Galli et al., 2001). The helminth fauna of ornamental fishes may jeopardize native and cultured fish populations (Tavares-Dias et al., 2010). Thereby, the knowledge about the parasites that can be harbored in fishes and the aspects linked with taxonomy, ecology and biology can assist the development of prevention and treatment (Eiras et al., 2010). However, only a few Brazilian wild freshwater ornamental fish had their parasite fauna assessed (Fujimoto et al., 2013; Tavares-Dias et al., 2010).

The family Anisakidae is of great importance to public health due to its zoonotic potential (Takemoto et al., 2009). Nematodes of the genus Hysterothylacium Moravec, Kohn et Fernandes, 1993 have been recorded in Chile (Carvajal and González, 1990), Brazil (Eiras and Rego, 1987), Kuwait (Petter and Sey, 1997), Yugoslavia (Petter and Radujkovic, 1986), Japan (Yoshinaga et al., 1989), and United States (Moser and Hsieh, 1992). Hysterothylacium spp. parasitizes freshwater fishes of several families (Deardorff and Overstreet, 1981a, b), including species from Brazilian river basins (Luque et al., 2011; Franceschini et al., 2013).

This study reports for the first time infections with Hysterothylacium sp. larvae in $H$. eques from the Paranapanema River, Jurumirim Reservoir, São Paulo State, Brazil.

\section{Material and Methods}

A sample of 33 specimens of $H$. eques was collected in a lentic stretch (marginal lagoon) of the Paranapanema River, Jurumirim Reservoir, municipality of Paranapanema, São Paulo State, Brazil (2331'22.81'S 48³7'56.99'W), using sieve nets in a stretch close to a macrophyte bank, in October, 2011. Subsequently, the fish specimens were placed in individual plastic bags and frozen. The samples were taken to the laboratory to perform parasitological analyses. The standard length $(\mathrm{cm})$ and total weight (grams) of the specimens were measured.

Skin, fins, nasal cavity, the inner face of the operculum, and the gills of the fish hosts were examined under a stereomicroscope to find helminth ectoparasites. A longitudinal incision in the ventral surface was made and all inner organs were removed and separated. The visceral cavity and all organs were surveyed for helminth parasites using a stereomicroscope. All collected helminthes were preserved in alcohol $70 \%$, and the nematodes were diaphanized using lactophenol to visualize the inner structures (Eiras et al., 2006).

The nematode larvae were analyzed using the computerized system for image analysis Qwin Lite 3.1 (Leica) and identified based on Moravec (1998). Helminth voucher specimens were deposited in the Coleção Helmintológica do Instituto de Biociências (CHIBB), UNESP, municipality of Botucatu, São Paulo State, Brazil, under the numbers CHIBB 7173 and 7180. Illustrations were performed with a drawing tube connected to a Leica DMLE microscope; and afterward the images were processed in the software CorelDraw X6.

The prevalence, mean intensity of infection, and mean abundance were determined according to Bush et al. (1997). The prevalence is the number of hosts infected with one or more individuals of a particular parasite species (or taxonomic group) divided by the number of hosts examined for that parasite species. The mean intensity of infection is the total number of parasites of a particular species found in a sample divided by the number of hosts infected with that parasite. Lastly, the mean abundance is the total number of individuals of a particular parasite species in a sample of a particular host species divided by the total number of hosts of that species examined (including both infected and uninfected hosts).

\section{Results}

Among the 33 fish analyzed (length $2.6 \pm 0.4 \mathrm{~cm}$, weight $0.5 \pm 0.2 \mathrm{~g}$ ), four specimens of $H$. eques were parasitized by Hysterothylacium sp. larvae (Figure 1), showing a prevalence of $12.1 \%$, mean intensity of infection of 1 , and mean abundance of $0.121 \pm 0.05$; one larva was found in the intestine and three larvae were found in the coelomic cavity. Additionally, a total of 40 unidentified free living nematodes were found in the stomach content of 17 fish (Figure 2). 


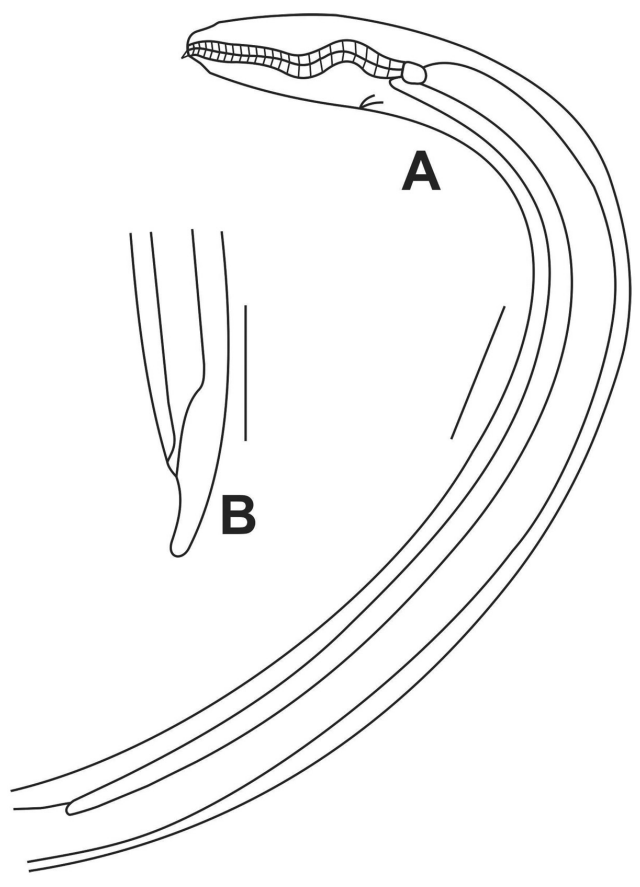

Figure 1. Hysterothylacium sp. larva collected in a specimen of Hyphessobrycon eques from Paranapanema River, Jurumirim Reservoir, municipality of Paranapanema, São Paulo State, Brazil. CHIBB number 7173. (A) Anterior extremity, (B) Posterior end. Scale bar: $100 \mu \mathrm{m}$.

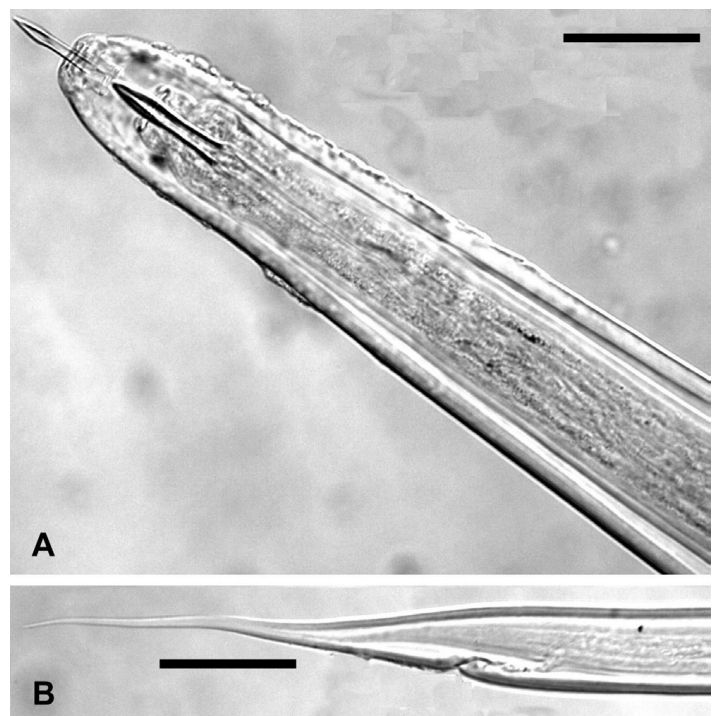

Figure 2. Non-identified free-living nematode collected in stomach of a specimen of Hyphessobrycon eques from Paranapanema River, Jurumirim Reservoir, municipality of Paranapanema, São Paulo State, Brazil. CHIBB number 7180. (A) Scale bar: $50 \mu \mathrm{m}$. (B) Scale bar: $100 \mu \mathrm{m}$.

\section{Discussion}

The helminth fauna of ornamental fishes may jeopardize native and cultured fish populations, thus the knowledge of ornamental fish health is important to avoid diseases
(Tavares-Dias et al., 2010). Furthermore, the assessment of fish parasites fauna and the aspects linked with taxonomy, ecology and biology may aid the development of prevention and treatment (Eiras et al., 2010).

Hyphessobrycon eques is distributed along the Amazonas and Paraná-Paraguai river basins (Weitzman and Palmer, 1998). However, its occurrence in the Upper Paraná River may be related to its use by aquarists (Graça and Pavanelli, 2007). Brandão et al. (2009) recorded this species in the Paranapanema River, which classifies H. eques as an allochthonous species in this area. Allochthonous species are those that come from other hydrographic basins, although in the same continent (Britski, 1994). The construction of hydroelectric power plants may enable species that are geographically isolated to occupy other areas, as it has been occurring in the Upper Paraná River basin (Smith et al., 2005). Moreover, the Paranapanema River is suffering several environmental disturbances because of the hydrological regime imposed by the impoundments (Carvalho, 2009). Such disturbances include the introduction of species that may affect the native fauna due to competition, predation, habitat and genetic alteration, and introduction of pathogens and parasites (Agostinho et al., 2007). When an organism infected with parasites is introduced, it may bring along part or all of its native parasites, which can cause, in a short term, the establishment of these parasites, decreasing of native species recruitment, and alterations in the populational structure; meanwhile, in a long term, the introduction of parasites can bring about alterations in the community structure, trophic structure, species extinction, decreasing of fishery resources quality, and modifications upon evolutionary pressures (Lacerda et al., 2013).

There are only a few recent studies on parasites of Brazilian wild freshwater ornamental fishes. Tavares-Dias et al. (2010) assessed the parasite fauna of eight species from the middle Negro River, Amazonas State, Brazil, recording Monogenea, Ciliophora, Dinoflagellida and Nematoda. Even though $H$. eques is largely appreciated all over the world, the literature reports only one study on its parasite fauna. Fujimoto et al. (2013) recorded for the first time seasonal occurrence of $Q$. nickoli cystacanths in H. eques from the Chumucuí River, Pará State, Brazil.

Nematodes of the family Anisakidae are important agents of parasitic diseases in humans, known as anisakidosis (Ubeira et al., 2000). Hysterothylacium sp. larvae have been reported in many Neotropical freshwater fish (Luque et al., 2011). Hysterothylacium spp. in natural conditions reach sexual maturity in the digestive tract of bony fish (Køie, 1993) or in marine mammals (Deardorff and Overstreet, 1982); whereas copepod, polychaet and other invertebrates are frequently used as intermediate hosts, and their larvae can also occur encapsulated in fishes (Yoshinaga et al., 1989; Køie, 1993). Nematodes may affect the behavior and physiology of fish, impair growth and sexual maturation, and turn them more susceptible to pollutants. Furthermore, Hysterothylacium spp. larvae entering the body of young fish may cause harm and even 
death (Berland, 1998). Regarding the ornamental potential of $H$. eques and the pernicious potential of nematode parasites, infections with Hysterothylacium sp. larvae may affect the biology of this fish and bring about profit losses to aquarists.

Crippa et al. (2009) assessed the food resource used by small-sized fish in macrophyte patches in ponds of the upper Paraná River floodplain, and found predominance of microcrustaceans in the diet of $H$. eques placing this fish into the zooplanktophagous trophic category. Santana-Porto and Andrian (2009) studied the trophic organization of the ichthyofauna of two semi-lentic environments in a flood plain on the upper Paraná River, Brazil and also placed H. eques into the category zooplanktophagous due to the high amount of Cladoceran found in the stomach content. Casatti et al. (2003) studied the spatial distribution and the diet of of $H$. eques sampled during the wet and dry seasons in the Rosana Reservoir, Southeastern, Brazil. Those authors observed $H$. eques schools dwelling the water column next to the substrate, thrusting against roots of macrophytes or the substrate to catch small prey items, and feeding mainly on dipteran larvae, Copepoda, Cladocera and Ostracoda. Additionally, they recorded nematode parasites in six stomachs however they do not make clear what nematode parasite species was found, which does not corroborate this study because we only found unidentified free living nematodes in the stomach. This study complements data on the diet of $H$. eques due to the records of unidentified free living nematode as part of the stomach content.

Fish can act as intermediate, paratenic or definitive hosts of nematodes (Anderson, 2000) and small crustaceans, like Copepoda, act as first intermediate host (Eiras et al., 2010). Considering the studies on the diet of $H$. eques, the larval stage of Hysterothylacium sp. and the infection site found in H. eques in this study, it can be suggested that this fish may ingest small crustaceans infected with Hysterothylacium sp. larvae, and act as second intermediate host for this nematode.

This study records for the first time infections with Hysterothylacium sp. larvae in $H$. eques from the Paranapanema River, Jurumirim Reservoir, São Paulo State, Brazil, and broads the knowledge about the helminth fauna of this fish, which may assist in developing prevention and treatment for the species.

\section{Acknowledgements}

The authors thank FAPESP (2010/19543-6) and CAPES (AUX-PE-PNPD 3005/2010) for funding the project, CAPES for the scholarship granted to the first author; the Laboratório de Ecologia e Biologia de Peixes for supporting the field trips; and Professor Edmir Daniel Carvalho who co-advised the first author but unfortunately is no longer with us to see the results of this study.

\section{References}

AGOSTINHO, AA., GOMES, LC. and PELICICE, FM., 2007. Ecologia e manejo de recursos pesqueiros em reservatórios do Brasil. Maringá: Eduem. 501 p.

ANDERSON, RC., 2000. Nematodes parasites of vertebrates: their biology and transmission. Wallingford: CABI Publishing. $672 \mathrm{p}$.

BERLAND, B., 1998. Biology of Hysterothylacium species. Parasitology International, vol. 47, supplement 1, p. 1-26.

BRANDÃO, H., VIDOTTO-MAGNONI, AP., RAMOS, IP. and CARVALHO, ED., 2009. Assessment of the ichthyofauna in stretches under the influence of Salto Grande Reservoir (Middle Paranapanema River, SP/PR, Brazil). Acta Limnologica Brasiliensia, vol. 21, no. 4, p. 451-463.

BRITSKI, HA., 1994. A fauna de peixes brasileiros de água doce e o represamento de rios. In Cadernos do Seminário sobre a fauna aquática e o setor elétrico, 1994. Rio de Janeiro. Rio de Janeiro: COMASE/ELETROBRÁS. p. 23-30.

BUSH, AO., LAFFERTY, KD., JEFFREY, ML. and SHOSTAK, AW., 1997. Parasitology meets ecology on its own terms. The Journal of Parasitology, vol. 83, no. 4, p. 575-583.

CARRASCHI, SP., CUBO, P., SCHIAVETTI, BL., SHIOGIRI, NS., CRUZ, C. and PITELLI, RA., 2011. Efeitos tóxicos de surfactantes fitossanitários para o peixe mato grosso (Hyphessobrycon eques). Acta Scientiarum. Biological Sciences, vol. 33, no. 2, p. 191-196.

CARVAJAL, J. and GONZALEZ, L., 1990. Presence of Hysterothylacium sp. (Nematoda: Anisakidae) in a cage-cultured coho salmon in Chile. Revista Chilena de Historia Natural, vol. 63, p. 165-168

CARVALHO, LN. and DEL-CLARO, K., 2004. Effects of predation pressure on the feeding behavior of the serpa tetra Hyphessobrycon eques (Ostariophysi, Characidae). Acta Ethologica, vol. 7, p. 89-93.

CARVALHO, ED., 2009. Ações antrópicas e a biodiversidade Jurumirim (Alto Rio Paranapanema). Botucatu: Instituto de Biociências de Botucatu. 91 p. Tese de Livre-Docência.

CARVALHO, FR., 2011. Sistemática de Hyphessobrycon Durbin, 1908 (Ostariophysi: Characidae). Porto Alegre: Universidade Federal do Rio Grande do Sul. 340 p. Doctoral Thesis in Animal Biology.

CASATTI, L., MENDES, HF. and FERREIRA, KM., 2003. Aquatic macrophytes as feeding site for small fishes in the Rosana Reservoir, Paranapanema River, Southeastern Brazil. Revista Brasileira de Biologia = Brazilian Journal of Biology, vol. 63 , no. 2, p. 213-222.

CRIPPA, VEL., HAHN, NS. and FUGI, R., 2009. Food resource used by small-sized fish in macrophyte patches in ponds of the upper Paraná river floodplain. Acta Scientiarum. Biological Sciences, vol. 31, no. 2, p. 119-125.

DEARDORFF, TL. and OVERSTREET, RM., 1981a. Review of Hysterothylacium and Iheringascaris (both previously = Thynnascaris) (Nematoda: Anisakidae) from the northern Gulf of Mexico. Proceedings of the Helminthological Society of Washington, vol. 93, p. 1035-1079.

DEARDORFF, TL. and OVERSTREET, RM., 1981b. Larval Hysterothylacium (=Thynnascaris) (Nematoda:Anisakidae) from fishes and invertebrates in the Gulf of Mexico. Proceedings of the Helminthological Society of Washington, vol. 48, p. 113-126.

DEARDORFF, TL. and OVERSTREET, RM., 1982. Hysterothylacium pelagicum sp. n. and Hysterothylacium cornutum (Stossich, 1904) (Nematoda: Anisakidae) from Marine Fishes. Proceedings of the Helminthological Society of Washington, vol. 49, p. 246-251. 
DUKE ENERGY, 2008. Peixes do rio Paranapanema. 2nd ed. São Paulo: Horizonte Geográfico. 120 p.

EIRAS, JC. and REGO, AA., 1987. The histopathology of Scomber japonicus infection by Nematobothrium scombri (Trematoda: Didymozoidae) and of larval anisakid nematode infections in the liver of Pagrus pagrus. Memorias do Instituto Oswaldo Cruz, vol. 82, p. 155-159.

EIRAS, JC., TAKEMOTO, RM. and PAVANELLI, GC., 2006. Métodos de estudo e técnicas laboratoriais em parasitologia de peixes. 2nd ed. Maringá: Eduem. 199 p.

EIRAS, JC., TAKEMOTO, RM. and PAVANELLI, GC., 2010. Diversidade de peixes de água doce do Brasil. Maringá: Clichetec. 333 p.

ESCHMEYER, WN. and FONG, JD., 2011. Catalog of Fishes electronic version. Species of Fishes by family/subfamily. California Academy of Sciences. Available from: $<$ http://researcharchive. calacademy.org/research/ichthyology/catalog/SpeciesByFamily. asp>. Access in: 10 Aug. 2015.

FRANCESCHINI, L., ZAGO, AC., ZOCOLLER-SENO, MC., VERÍSSIMO-SILVEIRA, R., NINHAUS-SILVEIRA, A. and SILVA, RJ., 2013. Endohelminths in Cichla piquiti (Perciformes, Cichlidae) from the Paraná River, São Paulo State, Brazil. Revista Brasileira de Parasitologia Veterinária, vol. 22, no. 4, p. 475-484.

FUJIMOTO, RY., ALMEIDA, ES., DINIZ, DG., EIRAS, JC. and MARTINS, ML., 2013. First occurrence of Quadrigyrus nickoli (Acanthocephala) in the ornamental fish Hyphessobrycon eques. Revista Brasileira de Parasitologia Veterinária, vol. 22, no. 1, p. 110-113.

GALLI, P., CROSA, G., MARINIELLO, L., ORTIS, M. and D'AMELIO, S., 2001. Water quality as a determinant of the composition of fish parasites communities. Hydrobiologia, vol. 452, p. 173-179.

GRAÇA, WF. and PAVANELLI, CS., 2007. Peixes da planície de inundação do alto Paraná e áreas adjacentes. Maringá: Eduem. $241 \mathrm{p}$.

KØIE, M., 1993. Aspects of the life-cycle and morphology of Hysterothylacium aduncum (Rudolphi, 1802) (Nematoda, Ascaridoidea, Anisakidae). Canadian Journal of Zoology, vol. 7, p. 1289-1296.

LACERDA, ACF., YAMADA, FH., ANTONUCCI, AM. and DIAS, MT., 2013. Peixes introduzidos e seus parasitos. In PAVANELLI, GC., TAKEMOTO, RM. and EIRAS, JC. (Eds.). Parasitologia de peixes de água doce do Brasil. Maringá: Eduem. p. 169-193.

LIMA, FCT. and MOREIRA, CR., 2003. Three new species of Hyphessobrycon (Characiformes: Characidae) from the upper rio Araguaia basin in Brazil. Neotropical Ichthyology, vol. 1, no. 1, p. 21-33.

LIMA, FCT., MALABARBA, LR., BUCKUP, PA., SILVA, JFP., VARI, RP., HAROLD, A., BENINE, R., OYAKAWA, O., PAVANELLI, CS., MENEZES, NA., LUCENA, CAS., MALABARBA, MCSL., LUCENA, ZMS., REIS, RE., LANGEANI, F., CASATTI, L., BERTACO, VA., MOREIRA, C. and LUCINDA, PHF., 2003. Characidae. In REIS, RE., KULLANDER, SO. and FERRARISJUNIOR, CJ. (Eds.). Check list of the freshwater fishes of South and Central America. Porto Alegre: Edipucrs. p. 106-169.

LUQUE, JL., AGUIAR, JC., VIEIRA, FM., GIBSON, DI. and SANTOS, CP., 2011. Checklist of Nematoda associated with the fishes of Brazil. Zootaxa, vol. 3082, p. 1-88.

MORAIS, FAB., 2013. Alimento inerte e vivo no desempenho do mato grosso, (Hyphessobrycon eques). Jaboticabal: Universidade Estadual Paulista. 72 p. Master Thesis in Aquaculture.
MORAVEC, F., 1998. Nematodes of freshwater fishes of the Neotropical Region. Czech Republic: Academia Praha. 464 p.

MOSER, M. and HSIEH, J., 1992. Biological tags for stock separation in pacific herring Clupea harengus Pallasi in California. The Journal of Parasitology, vol. 78, no. 1, p. 54-60.

PAN, CH., CHIENG, YH. and WANG, YJ., 2011. Antioxidant defense to ammonia stress of characins (Hyphessobrycon eques Steindachner) fed diets supplemented with carotenoids. Aquaculture Nutrition, vol. 17, p. 258-266.

PELICICE, FM. and AGOSTINHO, AA., 2005. Perspectives on ornamental fisheries in the upper Paraná River floodplain, Brazil. Fisheries Research, vol. 72, p. 109-119.

PELICICE, FM., AGOSTINHO, AA. and THOMAZ, SM., 2005. Fish assemblages associated with Egeria in a tropical reservoir: investigating the effects of plant biomass and diel period. Acta Oecologica, vol. 27, p. 9-16.

PETTER, AJ. and RADUJKOVIC, BM., 1986. Nématodes parasites de poisson de la mer Adriatique. Bulletin de la Musee d'Histoire Naturelle de Paris, vol. 8, p. 487-499.

PETTER, AJ. and SEY, O., 1997. Nematode parasites of marine fishes from Kuwait, with a description of Cucullanus trachinoti n. sp. from Trachinotus blochi. Zoosystema, vol. 19, p. 35-59.

SANTANA-PORTO, EA. and ANDRIAN, IF., 2009. Trophic organization the ichthyofauna of two semi-lentic environments in a flood plain on the upper Paraná River, Brazil. Acta Limnologica Brasiliensia, vol. 21, no. 3, p. 359-366.

SMITH, WS., ESPÍNDOLA, ELG. and ROCHA, O., 2005. As espécies de peixes introduzidas no rio Tietê. In ROCHA, O., ESPÍNDOLA, ELG., FENERICH-VERANI, N., VERANI, JR. and RIETZLER, AC. (Eds.). Espécies invasoras em águas doces - estudos de caso e propostas de manejo. São Carlos: Editora Universidade Federal de São Carlos. p. 25-44.

TAKEMOTO, RM., PAVANELLI, GC., LIZAMA, MAP., LACERDA, ACF., YAMADA, FH., MOREIRA, LHA., CESCHINI, TL. and BELLAY, S., 2009. Diversity of parasites of fish from the Upper Paraná River floodplain, Brazil. Revista Brasileira de Biologia = Brazilian Journal of Biology, vol. 69, no. 2, p. 691-705.

TAVARES-DIAS, M., LEMOS, JRG. and MARTINS, ML., 2010. Parasitic fauna of eight species of ornamental freshwater fish species from the middle Negro River in the Brazilian Amazon Region. Revista Brasileira de Parasitologia Veterinária, vol. 19 , no. 2, p. 103-107.

UBEIRA, FM., VALINAS, B., LORENZO, S., IGLESIAS, R., FIGUEIRAS, A. and GARCIA-VILLAESCUSA, R., 2000. Anisaquiois y alergia. Um estúdio soroepidemiológico em la comunidad Autônoma Gallega. Xunta de Galicia: Conselleria de Sanidade e Serviços Sociais. 102 p. (Documentos Técnicos de Salud Publica, Série B, no. 24).

WEITZMAN, SH. and PALMER, L., 1997. A new species of Hyphessobrycon (Teleostei Characidae) from the Neblina region of Venezuela and Brazil, with comments on the putative "rosy tetra clade". Ichthyological Exploration of Freshwaters, vol. 7, no. 3, p. 209-242.

WEITZMAN, SH. and PALMER, L., 1998. Phantom tetras: a brief account of their ichthyological and aquarium history. Tropical Fish Hobbyist, vol. 46, no. 11, p. 124-132.

YOSHINAGA, T., OGAWA, K. and WAKABAYASHI, H., 1989. Life cycle of Hysterothylacium haze (Nematoda: Anisakidae: Raphidascaridinae). The Journal of Parasitology, vol. 75, no. 5, p. 756-763. 